$1-2000$

\title{
Demonstration of the onshore transport of larval invertebrates by the shoreward movement of an upwelling front
}

\author{
AL Shanks \\ $\mathrm{J}$ Largier \\ L Brink \\ J Brubaker \\ Virginia Institute of Marine Science \\ R Hooff
}

Follow this and additional works at: https://scholarworks.wm.edu/vimsarticles

Part of the Marine Biology Commons

\section{Recommended Citation}

Shanks, AL; Largier, J; Brink, L; Brubaker, J; and Hooff, R, Demonstration of the onshore transport of larval invertebrates by the shoreward movement of an upwelling front (2000). Limnology and Oceanography, 45(1), 230-236.

$10.4319 /$ lo.2000.45.1.0230

This Article is brought to you for free and open access by the Virginia Institute of Marine Science at W\&M ScholarWorks. It has been accepted for inclusion in VIMS Articles by an authorized administrator of W\&M ScholarWorks. For more information, please contact scholarworks@wm.edu. 
Emil Rydin

Uppsala University

Department of Limnology

Norbyvägen 20, 75236 Uppsala, Sweden

Brian Huser

Eugene B. Welch

University of Washington

Department of Civil and Environmental Engineering

Seattle, Washington 98195

\section{References}

Boers, P. C. M., T. E. Cappenberg, and W. van RaAphorst. 1993. The third international workshop on phosphorus in sediment. Summary and synthesis. Hydrobiologia 253: xi-xviii.

Boström, B., J. M. Andersen, S. Fleischer, And M. Jansson. 1988. Exchange of phosphorus across the sediment-water interface. Hydrobiologia 170: 133-155.

-, M. JANSSON, AND C. FoRSBERG. 1982. Phosphorus release from lake sediments. Ergeb. Limnol. 18: 5-59.

Cooke, G. D., E. B. Welch, S. A. Peterson, and P. R. Newroth. 1993. Restoration and management of lakes and reservoirs. Lewis.

HÅKAnsson, L., And M. JAnsson. 1983. Principles of lake sedimentology. Springer.

Hieltjes, A. H. M., and L. LiJKLema. 1980. Fractionation of inorganic phosphates in calcareous sediments. J. Environ. Qual. 9: 405-407.

Housomi, M., M. OKadA, AND R. Sudo. 1981. Release of phosphorus from sediments. Verh. Int. Ver. Limnol. 21: 628-633.

JAMES, W. F., J. W. BARKO, AND W. D. TAYLOR. 1991. Effects of alum treatment on phosphorus dynamics in a north-temperate reservoir. Hydrobiologia 215: 231-241.

Jensen, H. S., P. Kristensen, E. Jeppesen, And A. Skytthe. 1992.

\section{Acknowledgments}

This investigation was supported by the Valle foundation at the University of Washington and the Svenska Institutet.
Iron:phosphorus ratio in surface sediments as an indicator of phosphate release from aerobic sediments in shallow lakes. Hydrobiologia 235/236: 731-743.

Kennedy, R. H., J. W. Barko, W. F. James, W. D. TAYlor, And G. L. Godshalk. 1987. Aluminum sulfate treatment of a eutrophic reservoir: Rationale, application methods, and preliminary results. Lake Reserv. Manag. 3: 85-90.

LIJKLEMA, L. 1994. Nutrient dynamics in shallow lakes: Effects of changes in loading and role of sediment-water interactions. Hydrobiologia 275/276: 335-348.

Mortimer, C. H. 1941. The exchange of dissolved substances between mud and water in lakes. 1. J. Ecol. 29: 280-329.

- 1942. The exchange of dissolved substances between mud and water in lakes. 2. J. Ecol. 30: 147-201.

MurPhy, J., AND J. P. RILEY. 1962. A modified single-solution method for the determination of phosphate in natural waters. Anal. Chim. Acta 27: 31-36.

NÜRNBERG, G. 1998. Prediction of annual and seasonal phosphorus concentrations in stratified and polymictic lakes. Limnol. Oceanogr. 43: 1544-1552.

Portielje, R., AND L. LiJklema. 1993. Sorption of phosphate by sediments as a result of enhanced external loading. Hydrobiologia 253: 249-251.

PSEnNER, R. 1984. Phosphorus release patterns from sediments of a meromictic mesotrophic lake (Piburger See, Austria). Verh. Int. Ver. Limnol. 22: 219-228.

- B. Boström, M. Dinka, K. Pettersson, R. Puckso, And M. SAGER. 1988. Fractionation of phosphorus in suspended matter and sediment. Arch. Hydrobiol. Suppl. 30: 98-103.

Rydin, E., AND E. B. Welch. 1998. Aluminum dose required to inactivate phosphate in lake sediments. Water Res. 32: 29692976. , AND - Dosing alum to Wisconsin lake sediments based on possible in vivo formation of aluminum bound phosphate. Lake Res. Man. In press.

Welch, E. B., AND D. G. CoOKE. 1999. Effectiveness and longevity of phosphorus inactivation with alum. Lake Res. Man. 15: 5-27.

Received: 9 March 1999

Accepted: 9 September 1999

Amended: 27 September 1999

\section{Demonstration of the onshore transport of larval invertebrates by the shoreward movement of an upwelling front}

\begin{abstract}
Upwelling winds off North Carolina set up upwelling fronts. As the wind forcing relaxed following such a coastal upwelling event, we observed the upwelling front move onshore. The low-density surface water moved shoreward over the upwelled water, forming a convergence zone at the front. This shoreward-moving front concentrated and transported larvae. Larval sergestid shrimp, spionid polychaete larvae, and the veligers of Odostomia sp. and Bittium sp. were concentrated on the seaward side of the moving convergence. Blue crab megalopae were concentrated at the surface immediately seaward of the front. These data demonstrate that a
\end{abstract}

relaxing upwelling front can transport high concentrations of larvae shoreward over the inner shelf. This may be an important mechanism promoting the shoreward migration of larval invertebrates and fish.

Many coastal and estuarine invertebrates and fish produce planktonic larvae that over a period of weeks to months go through their development in the waters over the continental shelf. At the end of this period of development the late-stage 
larvae must migrate back to shore or an estuary in order to complete their development and recruit into the adult population. This onshore migration is a critical stage in the life cycle of these organisms and an area of active research. Roughgarden et al. (1991) hypothesized that larvae may be transported to shore following upwelling events as the upwelling front moves shoreward and, ultimately, collides with the coast. While this hypothesized mechanism of shoreward transport of larvae is intuitively appealing and has been used in several papers to explain temporal patterns of larval recruitment at the coast (Wing et al. 1995a,b; Miller and Emlet 1997), the hypothesis has not been tested, and no direct observations have been reported.

Upwelling-favorable coastal winds push the surface waters of the ocean offshore, which causes a drop in sea level at the coast (Csanady 1981). Denser water from depth is drawn to the surface, and as upwelling progresses the lower density surface waters are pushed farther offshore and the nearshore water column is filled with this cold and dense upwelled water. At some distance from the coast, a sharp boundary is found where the upwelled water and the less dense surface water meet; this surface front is known as the upwelling front. When upwelling-favorable winds relax (or reverse direction), this structure relaxes and the lower density surface water moves back toward the shore. The exact form of this relaxation is complex and may involve downwelling or weak upwelling winds in addition to the baroclinic pressure gradients. In the absence of strong wind stress and vertical mixing, the frontal interface is expected to remain intact. Furthermore, as the low-density water approaches the shore and encounters shallower water, the effect of earth's rotation decreases and the upwelling front can be viewed as the head of a low-density surface gravity current moving shoreward over the denser upwelled water. In this paper, however, we do not attempt to resolve the complex interplay of baroclinic pressure gradients, surface wind stress, and coriolis/rotation effects. We simply note that the relaxation and shoreward movement of the offshore surface water and upwelling front results in a shoreward-moving surface convergence. The speed of movement depends on the relative importance of density, wind, and rotation effects (Simpson 1997).

As the less dense offshore surface water moves shoreward, it overrides the denser upwelled water, forming a convergence where the denser water subducts beneath the spreading surface water (Fig. 1). Within the spreading surface layer, the lower part is in contact with the stationary lower layer and this part of the surface layer moves slower than the overall feature. In response to this, the upper part of this surface layer moves faster than the overall feature, resulting in a surface convergence in the vicinity of the front. The surface convergence and associated downward flow is thus two sided, with surface flow toward the front from both sides (within a frame of reference moving with the front; see Fig. 1).

As the upwelling front moves shoreward, its affect on the distribution and movement of different larvae depends on the behavior of the specific larvae (modeled in Franks 1992). Larvae that have no strong depth preference or vertical orientation will simply be swept through the convergence zone and will not be concentrated or transported by the front.

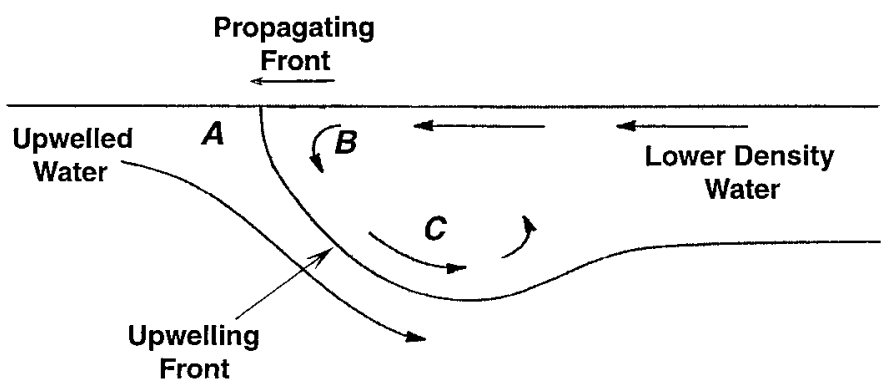

Fig. 1. Schematic diagram of an upwelling front propagating shoreward. As the less dense offshore surface water moves shoreward it overrides the denser upwelled water, forming a convergence where the denser water subducts beneath the spreading surface water. Within the spreading surface layer, the lower part is in contact with the stationary lower layer, and this part of the surface layer moves slower than the overall feature. In response to this, the upper part of this surface layer moves faster than the overall feature, resulting in a surface convergence within the frontal region. Organisms which can maintain position at the ocean's surface, due either to their buoyancy or their swimming ability, may become concentrated at $\mathrm{A}, \mathrm{B}$, or $\mathrm{C}$ (see text for further explanation).

Larvae that reside preferentially in the near-surface waters and are strong enough swimmers to overcome the downward flow at the convergence should, depending on the side from which they originate, become concentrated on either side of the upwelling front (A and B in Fig. 1). However, if larvae are weaker swimmers or if their behavioral response is slower, then they will be swept downward before rising again to the surface. Irrespective of the side of the front on which they originate, these larvae will end up on the low-density side of the front, forming a concentration broadly distributed around C (Fig. 1).

Methods-Observations of a shoreward-moving upwelling front and associated larval distributions were made as part of the coastal ocean processes (CoOP) interdisciplinary study of cross-shelf larval transport, which took place from August to October 1994 over the inner shelf adjacent to Duck, North Carolina. The primary observations were obtained from the R/V Hatteras during a 26-h station located in $15 \mathrm{~m}$ of water and $1.8-\mathrm{km}$ offshore of Duck, NC $\left(75.7318^{\circ} \mathrm{N}, 36.1955^{\circ} \mathrm{W}\right)$. We obtained depth profiles of temperature and salinity every half hour (using a SeaBird 911 Plus CTD). Simultaneous with the CTD cast, a high-frequency (1.2 MHz) RD Instruments acoustic Doppler current profiler (ADCP) was used to obtain a vertical profile of currents. The ADCP was mounted on a catamaran that held the transducer at a depth of $0.4 \mathrm{~m}$. Velocity profiles were made with a vertical resolution of $1 \mathrm{~m}$ and recorded at 1 to $2 \mathrm{~Hz}$. A detailed description of the collection and processing of the physical oceanographic data can be found in Waldorf et al. (1995). In addition to the ship-board physical data, temperature and salinity profile data and near-surface underway data were collected with an Ocean Sensors OS-200 CTD from a small boat. On three occasions during the ship anchor station, data were collected between the shore and 5-km offshore. A near-surface tow also provided high-resolution qua- 


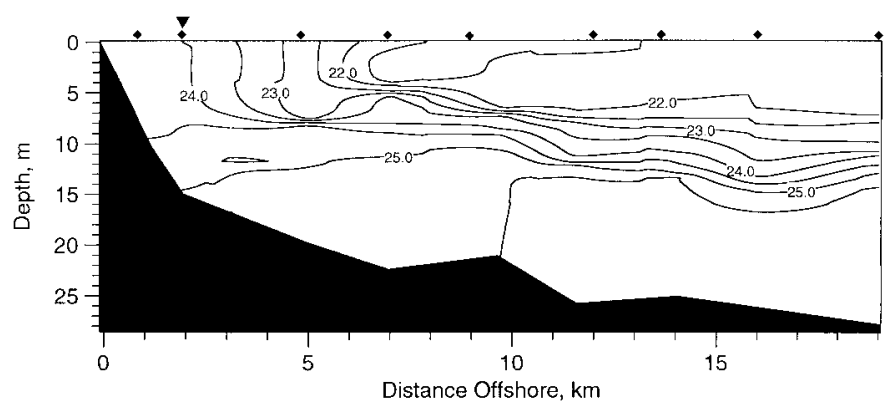

Fig. 2. Distribution of density (Sigma $\tau$ ) on a transect sampled the day before the start of the anchor station (21 August, 233.63 to 233.98 GMT) during a period of upwelling winds. CTD profiles were obtained at 15 locations, with a spacing of $1-2 \mathrm{~km}$ within 20 $\mathrm{km}$ of the shore. The diamond symbols along the upper horizontal axis indicate the location of the stations sampled for plankton. The $x$ symbol on the upper horizontal axis indicates the location of the anchor station, and the arrow indicates the location of the upwelling front.

si-instantaneous data on the cross-shore distribution of temperature and salinity (spatial resolution of about $10 \mathrm{~m}$ ).

On the ship, plankton samples were collected every hour with a centrifugal pumping system. A 5-cm diameter hose was connected to the CTD rosette and a deck-mounted pump. Output from the CTD provided information on the depth and water type from which each sample was collected. Flow from the pump was passed through a $100-\mu \mathrm{m}$ net suspended in a large tube of water. The pumping rate was 227 $\mathrm{L} \mathrm{min}^{-1}$, and 680 liters were sampled at each depth. Samples were collected at depths of $2,5,8,10$, and $12 \mathrm{~m}$ and preserved in buffered formalin. Observations began on $22 \mathrm{Au}-$ gust 1994 at $0600 \mathrm{~h}$ local time $(1100 \mathrm{~h}$ Greenwich Mean Time [GMT]) and ended $26 \mathrm{~h}$ later, on 23 August at $0800 \mathrm{~h}$ local time (1300 h GMT).

The plankton samples were sorted under a dissecting microscope. Crustaceans were counted in the entire sample. For the smaller more abundant organisms, subsamples were counted using the following procedure. The samples were washed free of formalin on a 53- $\mu \mathrm{m}$ sieve, transferred to a 250-ml beaker, and, with the aid of an electronic balance, made up to $200 \mathrm{ml}(200 \mathrm{~g})$. The sample was homogenized by vigorous stirring, and a 12-ml subsample was removed with a Stempel pipette (Peterson et al. 1979; Omori and Ikeda 1984). Subsamples were counted until at least 100 individuals of the most common organisms had been enumerated. This yielded a sample standard deviation of approximately $10 \%$ for the most abundant organisms and between 10 and 20\% for the less common species (Venrick 1978). To test the subsampling technique, we compared the number of organisms in four samples determined by subsampling and by counting the entire sample. No statistically significant differences (Mann-Whitney $U$-test, $P>0.05$ ) were found between the number of organisms determined by the two methods, which indicates that the subsampling technique adequately described the samples.

Results-Southwest winds (upwelling favorable) started on 18 August, $4 \mathrm{~d}$ prior to this 26-h station. These winds varied in strength with a maximum upwelling-favorable

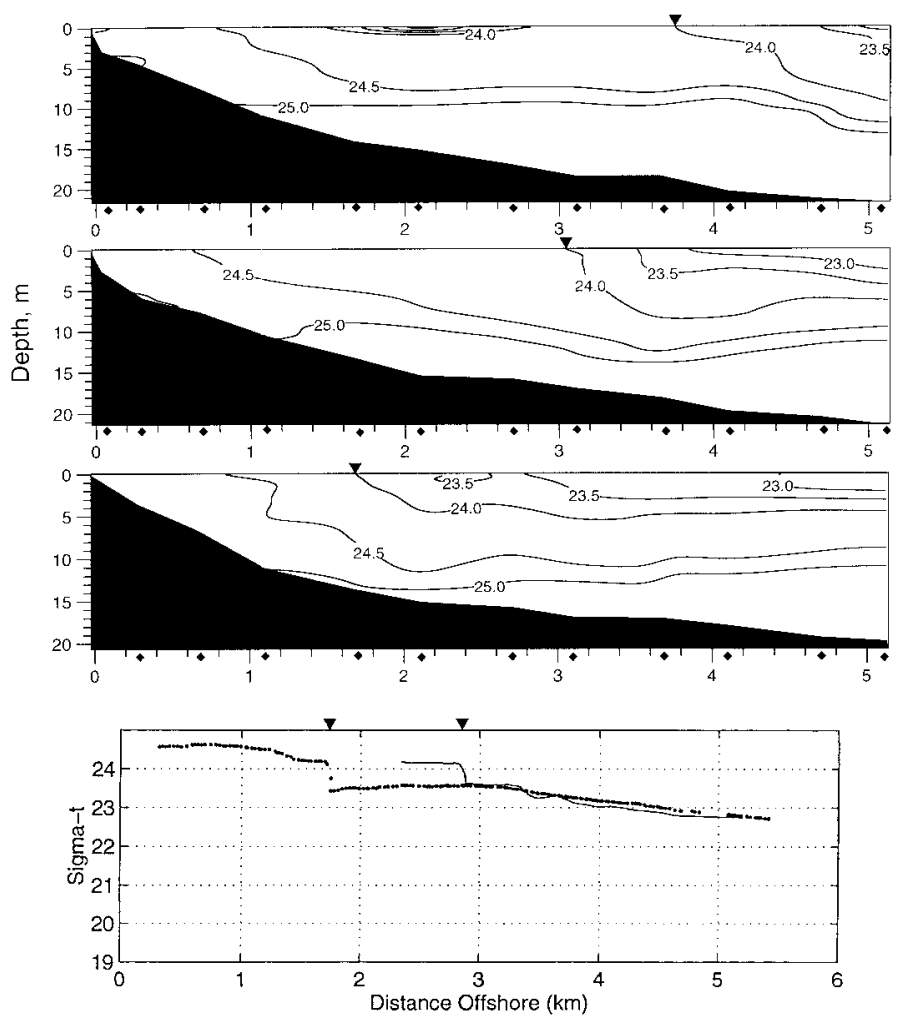

Fig. 3. Distribution of density (Sigma $\tau$ ) on a 5-km transect sampled three times on 22 August. The upper three panels are contour plots composed from 12 CTD profiles, spaced $0.2-$ to $0.5-\mathrm{km}$ apart, and completed at 1007, 1159, and $1510 \mathrm{~h}$ local time, respectively. The lower panel is a plot of near-surface Sigma $\tau$ as a function of distance offshore (data were collected quasi-instantaneously between 1228 and $1237 \mathrm{~h}$, and between 1524 and $1536 \mathrm{~h}$ local time). Data were obtained every $10 \mathrm{~m}$ and reflect the strong frontal interface at the leading edge of the frontal region. The anchor station was located approximately $2 \mathrm{~km}$ offshore. The arrow indicates the location of the upwelling front (as indicated by Sigma $\tau$ of 24.0).

component (10 $\mathrm{m} \mathrm{s}^{-1} \mathrm{~S}$ winds) during 21 August, immediately prior to the anchor station. Over the period 18 to 20 August a large-scale oceanographic survey of the study area was made. The survey extended $56 \mathrm{~km}$ north and south of the anchor station. On 20 and 21 August a small-scale oceanographic survey was made. This survey extended $20 \mathrm{~km}$ north and south of the anchor station. Late on 21 August, the cross-shore line on which the anchor station was located was again sampled. Throughout the study area and over this period we found active upwelling conditions with the upwelling front within $3 \mathrm{~km}$ of the shore (Fig. 2). Initially on 22 August, winds were light and upwelling favorable (Fig. 3). Downwelling winds started around $1525 \mathrm{~h}$ local time (234.85 GMT decimal day).

At the beginning of the anchor station the upwelling front had been pushed out past the position of the anchor station, and surface water salinities at the anchor station were $>34.0$ and densities were $>24.0$ Sigma $\tau$ (Fig. 3). In the series of nearshore CTD transects (Fig. 4), the surface front was located at about $3.8-\mathrm{km}$ offshore at $1000 \mathrm{~h}$ local time $(234.63$ GMT decimal day), at about 3.2-km offshore at $1130 \mathrm{~h}$ local 


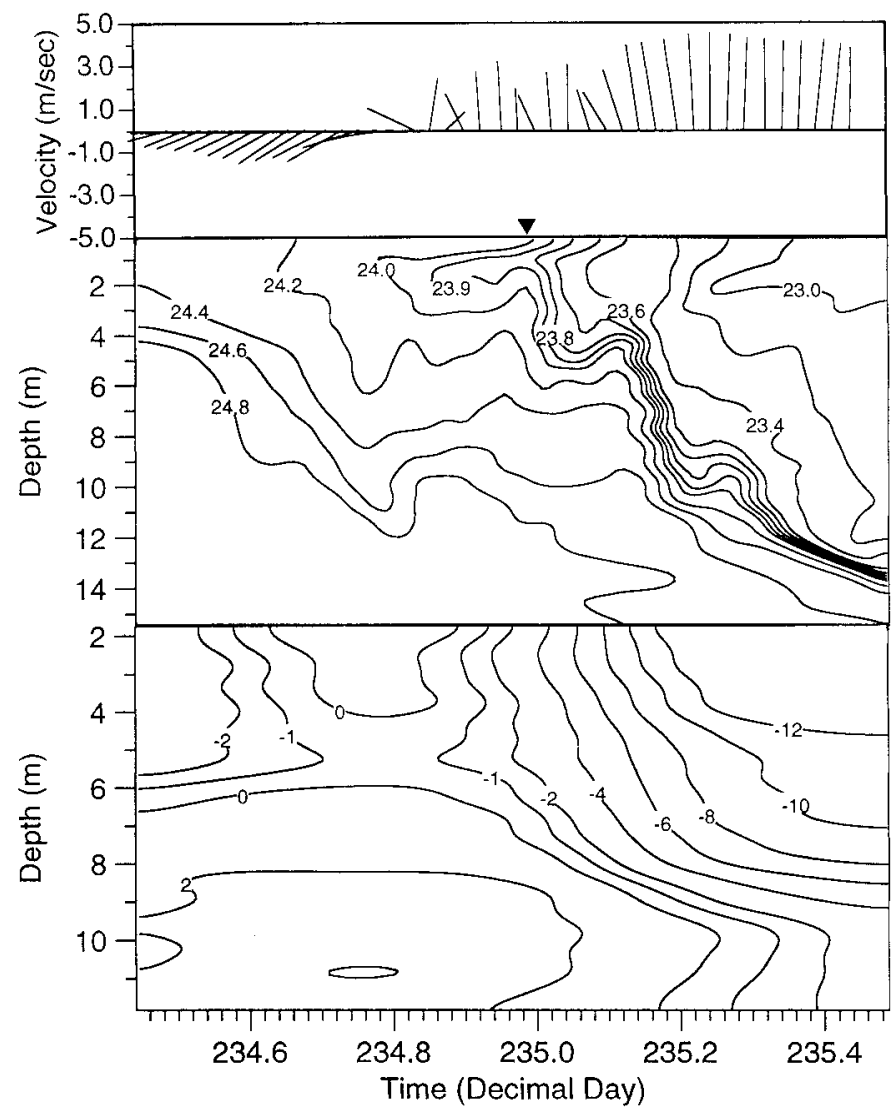

Fig. 4. Wind and oceanographic conditions during a 26-h anchor station off Duck, North Carolina (0600 h August 22 to 0800 $\mathrm{h}$ August 23 local). The horizontal axis in each figure is time in decimal day GMT. Figure A is a stick diagram of the hourly averaged wind speed and direction observed on the RV Cape Hatteras with vectors pointing up on the page representing winds blowing from the north. The coast and isobaths run approximately $20^{\circ}$ west of north, so that winds with a SSE component are upwelling favorable. Panel B is a contour plot of density (Sigma $\tau$ ). Panel C is a contour plot of the speed of the cross-shore current (in $\mathrm{cm} \mathrm{s}^{-1}$, with negative values indicating shoreward flow). The arrow indicates the location of the upwelling front.

time (234.69 GMT decimal day), and at about $1.8-\mathrm{km}$ offshore at $1500 \mathrm{~h}$ local time (234.83 GMT decimal day-using the position of the surface outcropping of the 24.0 Sigma $\tau$ isopycnal as an indicator of frontal position). More precise position of the upwelling front was obtained from high-resolution surface CTD tows (approximate sample depth of 1 $\mathrm{m}$ ), which show a 0.5 Sigma $\tau$ drop in density across a frontal interface (Fig. 4) that was observed at 2.83-km offshore at $1232 \mathrm{~h}$ local time (234.73 GMT decimal day) and at 1.73$\mathrm{km}$ offshore at $1531 \mathrm{~h}$ local time (234.85 GMT decimal day). The ship data do not provide an exact time of passage of the surface front, but it was between 234.84 and 234.9 GMT that at 1-m depth the 24.0 Sigma $\tau$ isopycnal first appeared under the ship, consistent with the position of the moving surface front in the repeated nearshore CTD surveys.

Concurrent with the appearance of the lower density water at the ship was the onset of a shoreward current (Fig. 3). Near-surface flow speeds increased from 0 to $-12 \mathrm{~cm} \mathrm{~s}^{-1}$ over about $7 \mathrm{~h}$. Having observed the spatial structure of the front both offshore and inshore of the ship, the decrease in density and onset of stronger shoreward flow can be interpreted as being due to the passage of the upwelling front beneath the ship. Prior to the front passing the ship, a downwelling-favorable wind began to blow, and the subsequent changes in density and flow structures reflect a combination of density-driven relaxation of the upwelling front and winddriven acceleration of near-surface flow. Both effects contribute to the continued shoreward movement of the front.

From the surface data shown in Fig. 4, the speed at which the front moved shoreward past the ship was calculated to be $10.2 \mathrm{~cm} \mathrm{~s}^{-1}$. Further, the difference in arrival time of given isopycnals at the ship and at an oceanographic mooring slightly to the south and approximately $1-\mathrm{km}$ landward of the ship $\left(36.1833^{\circ} \mathrm{N}, 75.7335^{\circ} \mathrm{W}\right)$ provides an additional estimate of shoreward speed of $11 \mathrm{~cm} \mathrm{~s}^{-1}$, consistent also with the movement of the front as observed in the nearshore CTD sections (Fig. 4) and with the expected propagation of a density-driven front. Porter et al. (1998) obtained similar propagation speeds at other times during the August-October observation period, and they also observed upwelling fronts moving into the surf zone.

Although the surface outcropping of the frontal interface clearly passed the ship at between 234.84 and 234.9 GMT, this feature was shallow (less than 4-m depth) and the associated flow structure was not well resolved by ADCP data that started at about 2-m depth. However, the subsurface density and velocity structure of the frontal feature was well resolved by these measurements (Fig. 3). The data suggest that there was a swath of convergent flow behind where the frontal interface intersects the surface. A rough estimate of the speed of downward flow in the front can be obtained from the principle of continuity, with assumptions that this moving feature evolves slowly in time and that there is little alongshore variation in this structure. Under these assumptions, the downward flow in the front must be sufficient to balance the convergence in horizontal currents. Using data from Fig. 3 and looking at the frontal region between 0 and $-0.12 \mathrm{~cm} \mathrm{~s}^{-1}$, one obtains a horizontal convergence of order $5 \times 10^{-5} \mathrm{~s}^{-1}$, which would result in a downwelling speed in the front of order $5 \times 10^{-4} \mathrm{~m} \mathrm{~s}^{-1}\left(0.5 \mathrm{~mm} \mathrm{~s}^{-1}\right)$ at the base of the convergent flow (at about 8-m depth). This downwelling occurs over a broad swath that passed the ship between about 234.90 and 235.17 GMT. Using a propagation speed of $10 \mathrm{~cm} \mathrm{~s}^{-1}$, this corresponds to a convergence swath that is about $2.3-\mathrm{km}$ wide.

For this shoreward-moving frontal feature to be effective at trapping and transporting larvae shoreward, it is necessary that fluid velocities exceed the speed of movement of the front. Given a frontal speed of $10.2 \mathrm{~cm} \mathrm{~s}^{-1}$, the recorded fluid velocities of greater than $12 \mathrm{~cm} \mathrm{~s}^{-1}$ suggest that this was a true convergence and capable of transporting material trapped in the front (the estimate of frontal propagation speed and ADCP observations of velocity have errors of $<1$ $\mathrm{cm} \mathrm{s}^{-1}$ ). The maximum subsurface density gradient occurs in the middle of this convergent flow structure. Below about 6-m depth, fluid velocities are too slow to overtake the moving frontal structure, and no true convergence is expected. It is also worth noting that the relative flow toward the mov- 


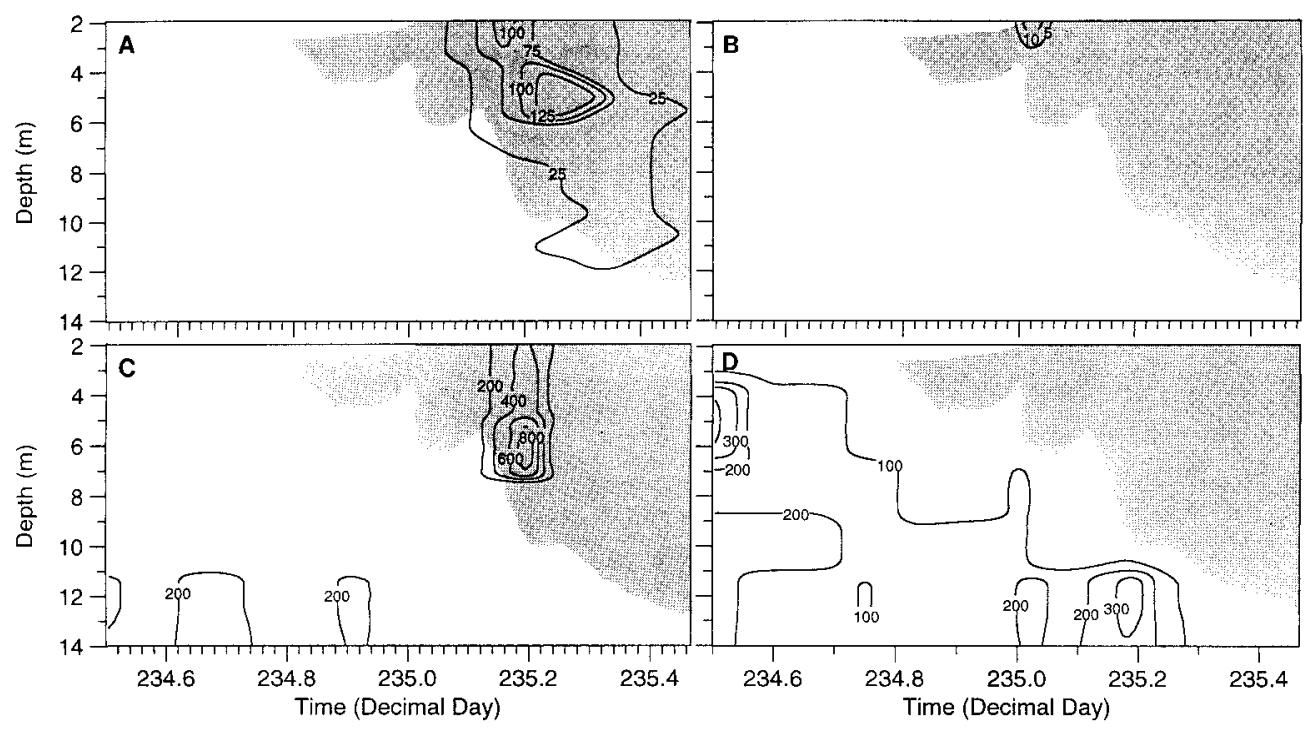

Fig. 5. Contour plots of larval concentrations (number $\mathrm{m}^{-3}$ ). The horizontal axis in each figure is time in decimal day GMT. The shaded area represents waters with density $<24.0$ Sigma $\tau$ - the low-density offshore surface waters. Concentrations of the larvae of the sergestid shrimp Lucifer faxoni, the megalopae of the blue crab Callinectes sapidus, larval spionid polychaetes, and the larvae of the bivalve Mya arenaria are contoured in panels A through D, respectively.

ing front is an order of magnitude stronger on the shoreward side than on the seaward side. Larvae within the seaward surface layer should be carried toward the front slowly. On this side of the front, a swath of only about $500 \mathrm{~m}$ would have been moved through the front as the front moved toward shore over a $5-\mathrm{km}$ swath of upwelled water.

During the period of upwelling, the dominant meroplanktonic larvae were bivalve and gastropod veligers. The distribution of Mya arenaria (Fig. 5) is typical of most of these organisms. During our sampling, $M$. arenaria veligers tended to be found in waters with densities $>24.4$ Sigma $\tau$ (Fig. 5). As upwelling ended and the denser waters were displaced by the less dense surface waters, $M$. arenaria veligers vanished from the water column under the anchored ship concurrent with the displacement of the dense upwelled waters (Figs. 3 and 5). This temporal change in the vertical distribution of these larvae suggests that they were behaving as passive particles imbedded in the flow structure.

In contrast, high concentrations of several other types of meroplanktonic larvae were observed as the upwelling front passed under the ship. Larvae of the sergestid shrimp Lucifer faxoni went from concentrations of zero in the upwelled waters to more than $125 \mathrm{~m}^{-3}$ in the front (Fig. 5). Peak concentrations were found in waters with densities between 23.4 and 23.2 Sigma $\tau$ and at sample depths of 2 and $5 \mathrm{~m}$, with the highest concentrations found around $5 \mathrm{~m}$. Concentrations at 8- and 10-m depth were much lower. At water densities outside this range, but within the low-density surface water layer, concentrations were about $25 \mathrm{~m}^{-3}$.

Larval spionid polychaetes and the veligers of the gastropods Odostomia sp. and Bittium sp. had distributions similar to that of L. faxoni larvae, but with a tighter and more exclusive distribution in the front. The distribution of the spionid larvae will be used as an example. In the upwelled waters, spionid larvae were found in patches near the bottom with concentrations of up to $200 \mathrm{~m}^{-3}$. Within the front, however, we found peak concentrations exceeding $800 \mathrm{~m}^{-3}$ with larvae primarily concentrated in waters with densities between 23.3 and 23.5 Sigma $\tau$ and at depths shallower than the $8-\mathrm{m}$ sample, with a peak in concentration around $5 \mathrm{~m}$ (Fig. 5). L. faxoni, spionid larvae, and the veligers of Odostomia sp. and Bittium sp. were concentrated immediately seaward of the core of the front, in the low-density surface waters. The distributions of these larvae suggest that their upward movement concentrated them in the presence of the downward flow associated with the horizontal convergence. Their distributions appear to correspond to scenario B or C in Fig. 1 and agree with the conclusions from a model developed by Franks (1992) describing the concentration of organisms around convergences.

A fourth species of interest is the blue crab Callinectes sapidus, the megalopae of which are inhabitants of the very surface of the ocean (Smyth 1980; Johnson 1985; Maris 1986). Concentrations of megalopae are generally $<1 \mathrm{~m}^{-3}$. The sampling for this study was not designed, nor expected, to catch these megalopae because the shallowest sampling depth was $2 \mathrm{~m}$ and the volume of water sampled was only $0.6 \mathrm{~m}^{3}$. As expected, no blue crab megalopae were collected in the upwelled waters. However, an extremely high concentration of $15 \mathrm{~m}^{-3}$ was observed at 2-m depth, seaward of where the frontal interface intersected the surface, but shoreward of the deeper convergence zone (Fig. 5) in water with a density of about 23.9 Sigma $\tau$. The location of their peak concentration probably corresponds to scenario B in Fig. 1.

Discussion-These observations demonstrate the concentration of selected larvae by an upwelling front and persistence of this concentration during movement of the front toward the shore. We understand all of these distributions to represent scenario $\mathrm{C}$ or $\mathrm{B}$ (Fig. 1). Particles that remain near 
surface by virtue of their buoyancy will respond instantaneously to resist downward transport by flow speeds slower than their "rising velocity," and one typically finds a foam line where the front intersects the surface. However, larvae that remain near surface by virtue of an active swimming response may exhibit a lag in their upward movement owing to delayed response or inadequate swimming ability. The delay and strength of their swimming response will result in variations of scenario C. The distributions of $L$. faxoni, spionid larvae, and the veligers of Odostomia sp. and Bittium sp. seem to match this pattern. The distribution of blue crab larvae (Fig. 5B) appears to match scenario B. This is consistent with the typical occurrence of these larvae at the very surface of the ocean and with their strong swimming ability (Shanks 1985). In contrast, the high concentrations of sergestid shrimp larvae (Fig. 5A) and spionid larvae (Fig. 5C) were not as close to the surface, and appear to be located in response to the deeper subsurface convergent flow. The observed distributions of larvae are consistent with the hypothesis that they swam up against the weak downward flow on the ocean side of the front. This is a reasonable expectation as observed or estimated swimming speeds of these larvae are significantly higher than the downward flow speeds estimated here (Chia et al. 1984).

Not only did this front concentrate larvae, but it also transported these larvae shoreward. As these observations were made from a fixed location over time, the appearance of these larvae under the ship when none had been there previously is a clear demonstration of their horizontal transport toward shore. Further, the distribution of larvae in the convergence zone agrees well with that modeled by Franks (1992). Given the estimated speed at which the upwelling front was moving shoreward and the expectation that upwelling fronts move into the surf zone (Porter et al. 1998), one can expect that the observed larval concentrations were delivered to the shallow nearshore within several hours of our observations.

Including this new observation, researchers have now described and observed three types of flow convergences that move shoreward and that can transport larvae from the continental shelf to the nearshore. This paper describes a moving convergence associated with a wind-driven upwelling front relaxing to shore. Others have described moving convergences associated with tidally generated internal waves over the continental shelf (Zeldis and Jellett 1982; Shanks 1983; Kingsford and Choat 1986; Shanks and Wright 1987; Shanks 1988). Still others describe a shoreward-moving convergence that may also be associated with the relaxation of an internal wave surge that fills the nearshore with dense water and results in a front that can move shoreward (Pineda 1994). For those organisms transported to shore by moving convergences, the temporal pattern of settlement (or recruitment) depends on the dominant type of moving convergence at a location. If the dominant form is due to large tidally generated internal waves or internal tidal bores, then we would expect settlement to vary with the spring-neap tidal cycle. This pattern of settlement has been observed for a number of organisms (Little 1977; Shanks 1986; Doherty and Williams 1988; Montfrans et al. 1990; Boyland and Wenner 1993; Olmi 1995; Shanks 1998). If instead the dom- inant form of moving convergence is due to upwelling fronts moving to shore, then we would expect peaks in settlement to occur immediately following upwelling events. This pattern of settlement has also been reported (Wing et al. 1995a,b; Miller and Emlet 1997).

Transport of larvae to the coast by moving convergences may also affect the alongshore distribution of settling larvae. Owing to variations in bottom topography, the production of tidally generated internal waves and bores is not evenly distributed along the coast (Sawyer 1983). Further, internal waves and bores are refracted by bottom topography (e.g., submarine canyons and ridges) so that they may be focused differentially along a coast. Variations in the alongshore production or refraction of internal waves may affect spatial settlement patterns (Shanks and Wright 1987).

Satellite-derived images of sea surface temperature following wind-driven upwelling events suggest that upwelling fronts relaxing back to shore do not impinge everywhere along a coast. This alongshore variation in upwelling and relaxation of upwelling has received attention off California (Largier et al. 1993; Wing et al. 1995a,b), and it appears that upwelling fronts contact shore north of many capes prior to contact south of the cape, if that occurs at all. This apparent alongshore difference in the contact of upwelling fronts might cause the observed alongshore differences in recruitment of intertidal invertebrates (Ebert and Russell 1988).

In this paper we present evidence that a relaxing upwelling front can transport high concentrations of larvae shoreward over the inner shelf, thus supporting a strong hypothesis for observed temporal and spatial patterns in the settlement and recruitment of nearshore invertebrates and reef fish. Previous research has demonstrated that moving convergences generated by the tides can also transport larvae shoreward. Wind-driven upwelling and tidally generated internal waves are common features of the continental shelves of the world. Hence, one may expect that the shoreward transport of the larvae of coastal invertebrates and fish by moving convergences is also a common phenomenon that needs to be better quantified and understood in the interests of understanding the ecology of nearshore populations and communities—benthic, pelagic, and estuarine.

Alan L. Shanks

Oregon Institute of Marine Biology

University of Oregon

P.O. Box 5389

Charleston, Oregon 97420

John Largier ${ }^{1}$

Scripps Institution of Oceanography

University of California

San Diego, California 92093-0209

Laura Brink

Horn Point Laboratory

University of Maryland

P.O. Box 775

Cambridge, Maryland 21613

\footnotetext{
${ }^{1}$ Present address: Department of Oceanography, University of Cape Town, Rondebosch, 7701, South Africa.
} 
John Brubaker

Virginia Institute of Marine Science

School of Marine Science

College of William and Mary

Gloucester Point, Virginia 23062

Rian Hooff

Oregon Institute of Marine Biology

University of Oregon

P.O. Box 5389

Charleston, Oregon 97420

\section{References}

Boyland, J. M., And E. L. Wenner. 1993. Settlement of brachyuran megalopae in a South Carolina, USA, estuary. Mar. Ecol. Prog. Ser. 97: 237-246.

Chia, F. S., J. Buckland-Nicks, and C. M. Young. 1984. Locomotion of marine invertebrate larvae: A review. Can. J. Zool. 62: $1205-1222$.

Csanady, G. T. 1981. Circulation in the coastal ocean. Adv. Geophys. 23: 101-183.

DOHERTY, P. J., AND D. M. WiLliams. 1988. The replenishment of coral reef fish populations. Mar. Biol. Annu. Rev. 26: 487551.

Ebert, T. A., AND M. P. Russell. 1988. Latitudinal variation in size structure of the west coast purple sea urchin: A correlation with headlands. Limnol. Oceanogr. 33: 286-294.

FRANKS, P. J. S. 1992. Sink or swim: Accumulation of biomass at fronts. Mar. Ecol. Prog. Ser. 82: 1-12.

Johnson, D. F. 1985. The distribution of brachyuran crustacean megalopae in the waters of the York River, lower Chesapeake Bay and adjacent shelf: Implications for recruitment. Estuar. Coast. Shelf Sci. 20: 693-705.

KingSFORD, M. J., AND J. H. ChOAT. 1986. The influence of surface slicks on the distribution and onshore movement of small fish. Mar. Biol. 91: 161-171.

Largier, J. L., B. A. Magnell, And C. D. Winant. 1993. Subtidal circulation over the northern California shelf. J. Geophys. Res. C 98: 18147-18179.

LitTle, E. J. J. 1977. Observations on recruitment of postlarval spiny lobsters, Panulirus argus, to the south Florida coast. Florida Marine Research, Pub. 29.

MARIS, R. C. 1986. Patterns of diurnal vertical distribution and dispersal-recruitment mechanisms of decapod crustacean larvae and postlarvae in the Chesapeake Bay, Virginia and adjacent offshore waters. Ph.D. thesis. Old Dominion Univ.

Miller, B. A., AND R. B. EMLet. 1997. Influence of nearshore hydrodynamics on larval abundance and settlement of sea urchins Stronglylocentrotus franciscanus and S. purpuratus in the Oregon upwelling zone. Mar. Ecol. Prog. Ser. 148: 83-94.

Montfrans, J. V., C. A. Peery, And R. J. Orth. 1990. Daily, monthly, and annual settlement patterns by Callinectes sapidus and Neopanope sayi megalopae on artificial collectors deployed in the York River, Virginia: 1985-1988. Bull. Mar. Sci. 46: $214-229$.

OLmi, E. J. III. 1995. Ingress of blue crab megalopae in the York River, Virginia, 1987-1989. Bull. Mar. Sci. 57: 753-780.
OMORI, M., AND T. IKEDA. 1984. Methods in marine zooplankton ecology. Wiley.

Peterson, W. T., C. B. Miller, And A. Hutchinson. 1979. Zonation and maintenance of copepod populations in the Oregon upwelling zone. Deep-Sea Res. 26: 467-494.

PINEDA, J. 1994. Internal tidal bores in the nearshore: Warm-water fronts, seaward gravity currents and the onshore transport of neustonic larvae. J. Mar. Res. 52: 427-458.

Porter, D. L., T. D. SiKora, AND M. D. Wiseup. 1998. Air-sea interaction associated with the relaxation of an upwelling event off the coast of Duck, North Carolina. EOS 79: 172.

Roughgarden, J., J. T. Pennington, D. Stoner, S. Alexander, AND K. Miller. 1991. Collisions of upwelling fronts with the intertidal zone: The cause of recruitment pulses in barnacle populations of central California. Acta Oecol. 12: 35-51.

SAWYER, C. 1983. A satellite study of ocean internal waves. NOAA, Tech. Memo. ERL-PMEL-46.

SHANKS, A. L. 1983. Surface slicks associated with tidally forced internal waves may transport pelagic larvae of benthic invertebrates and fishes shoreward. Mar. Ecol. Prog. Ser. 13: 311-315.

. 1985. The behavioral basis of internal wave induced shoreward transport of the megalopae of Pachygrapsus crassipes. Mar. Ecol. Prog. Ser. 24: 289-295.

. 1986. Tidal periodicity in the daily settlement of intertidal barnacle larvae and an hypothesized mechanism for the crossshelf transport of cyprids. Biol. Bull. 170: 429-440.

- 1988. Further support for the hypothesis that internal waves can transport larvae of invertebrates and fish onshore. Fish. Bull. 86: 703-714.

- 1998. Abundance of post-larval Callinectes sapidus, Penaeus spp., Uca spp., and Labinia spp. collected at an outer coastal site and their cross-shelf transport. Mar. Ecol. Prog. Ser. 168: $57-69$.

—, AND W. G. WRIGHT. 1987. Internal-wave-mediated shoreward transport of cyprids, megalopae, and gammarids and correlated longshore differences in the settling rate of intertidal barnacles. J. Exp. Mar. Biol. Ecol. 114: 1-13.

Simpson, J. E. 1997. Gravity Current in the Environment and the Laboratory. 2nd ed. Cambridge Univ. Press.

Smyth, P. O. 1980. Callinectes (Decapoda: Portunidae) larvae in the Middle Atlantic Bight, 1975-77. Fish. Bull. 78: 251-265.

VENRICK, E. L. 1978. How many cells to count? p. 167-180. In A. Sournia [ed.], Phytoplankton manual. UNESCO.

Waldorf, B. W., J. L. Largier, S. Rennie, J. Austin, and C. GREENGROvE. 1995. Coastal ocean process (CoOP) pilot project data report: R/V Hatteras shipboard measurements; underway, CTD and ADCP Data August 1994. Scripps Institution of Oceanography, La Jolla. 1-416.

Wing, S. R., L. W. Botsford, J. L. LARgier, And L. E. Morgan. 1995a. Spatial structure of relaxation events and crab settlement in the northern California upwelling system. Mar. Ecol. Prog. Ser. 128: 199-211.

—, J. L. Largier, L. W. Botsford, And J. F. Quinn. $1995 b$. Settlement and transport of benthic invertebrates in an intermittent upwelling region. Limnol. Oceanogr. 40: 316-329.

Zeldis, J. R., AND J. B. Jellett. 1982. Aggregation of pelagic Munida gregaria (Fabricius)(Decapoda, Anomura) by coastal fronts and internal waves. J. Plankton Res. 4: 839-857.

Received: 10 September 1998 Accepted: 24 September 1999 Amended: 7 October 1999 